\title{
THE LIFE CYCLE OF HORMAPHIS HAMAMELIDIS.
}

By T. H. Morgan and A. F. Shull.

Pergande* has described the life cycle of this species as consisting of seven generations, the first two and the sexual generations living on the witch hazel, and the other four on the black birch (Betula nigra), the latter four generations consisting of three aleurodiforms and one winged migrant.

Failure on our part to discover the aleurodiform generations in localities where the witch hazel was abundant, and the discovery that the winged migrants continued to emerge from the galls from the end of July until October, thus leaving no time for the intercalation of the four birch generations, led us to examine the life cycle of this species in the vicinity of New York.

Leaves of the witch hazel bearing galls of Hormaphis were enclosed in bags of paraffin paper about the first of August, when the migrants had begun to leave the gall. The bags were opened at intervals of about a week, and the under surface of the leaves examined. Nothing was found until about the first week in September, when the sexual forms were discovered on the leaves which had been in the bags. At the same time the sexual forms were also found on the leaves outside. The results show at least that the birch is not a necessary link in the life cycle of this species; and since no aleurodiform individuals were seen at any time on the witch hazel, their necessary occurrence in the life history seems, in this locality at least, to be excluded.

The final and conclusive evidence was obtained from a microscopic examination of the migrants within the witch hazel galls, and of the young stages, pupal and prepupal. Serial sections show that all these forms contain embryos that are males or females. The determination of the male embryos can be made owing to the fact that the testes early develop, and in the embryos in the winged stages of the migrant the characteristic spermatcoyte divisions can be found. In all of these, as in other aphids, a lagging chromosome is present, and two classes of sperm, functional and rudimentary, result. The determination of the sexual female can be made owing to the presence of a sypegesis stage in the eggs in the ovary.

* Pergande, Theo. "The Life History of Two Species of Plant-lice Inhabiting Both the Witch-Hazel and Birch." U. S. Dept. of Agr., Div. of Entomology, Technical Series No. 9, 1901. 
At Cold Spring Harbor, where these observations were made, three birches are present: Betula lenta is common, B. populifolia is uncommon, and B. lutea is rare. B. nigra is said to occur, but was not found. Winged migrants were placed on the leaves of the first three of these species in the evening; those on leaves of trees outside had left by 9 A. м. the next day; some of those on branches in the laboratory remained during the day, and were seen as late as 4 P. M., but had left by 8 A. M. on the following morning. They appear not to have deposited any young, since none appeared on the leaves during the following two weeks.

A branch of witch hazel with leaves bearing galls, and one of a birch (B. lenta), growing near together, were enclosed in the same bag. After about three weeks the bag was opened, when sexual individuals were found on the witch hazel leaves, but none on the birch.

The observations show that in the vicinity of New York, Hormaphis has a much simpler life history than that ascribed to this species by Pergande for the vicinity of Washington. It would seem to follow, either that further south there is a longer life cycle including an alternate host, or that Pergande has intercalated in the life cycle of this species several generations of some other (aleurodiform) species. Fortunately the question can be very simply decided by making a few serial sections of the winged migrants in the galls found in the District of Columbia.

Pergande's statement is so definite and detailed that it scarcely seems possible that he could be mistaken in regard to the life history of the Washington form. For example, he states on page I 7 , regarding the third generation: "Toward the middle or end of June the insects cast their third or final skin and assume a most remarkable mimicry; in fact, mimic now so closely certain Aleurodids that for some time I was completely deceived as to their true nature, which only after close examination of numerous specimens, in connection with its earlier stages, was disclosed. When seen on the leaves they are to all appearances true Aleurodids, both in shape and size, resembling to some extent the scalelike form of Aleurodes corni or related species." The fourth and fifth generations are also aleurodiform. "With the appearance of the sixth generation a new cycle of forms begins to make its appearance, in which the aspect of the insects has changed completely, so much so that the casual observer would fail to trace a connection between them and the Aleurodiform generations. 
Continued observations, both in the woods and on small potted birches to which the insects were transferred, removed, however, all doubt as to the close relationship of these aberrant forms. This generation develops in time into the return migratory generation."

The return of the migrants to the witch hazel is described by Pergande as follows (p. 2I): "Having cast their fourth or final skin, they acquire wings and, after feeding for some time to complete maturity, forsake the birch and migrate back to witch hazel to deliver themselves of the ultimate or sexual generation. Each migrant, according to size, contains from seven to fifteen or perhaps more larvae. Migration continues for about a month and a half, according to conditions of the season and other natural causes, and commences usually toward the end of August and terminates during the early part of-October. In general appearance they are essentially the same as those of the spring migrant from the witch hazel, though they are uniformly smaller $* * *$." From these statements it appears that Pergande has observed not only all the intermediate stages between the young of the spring migrants from the witch hazcl and the aleurodiform generations on the birch, but also the development of the return migrant from the aleurodiform individuals on small potted birches in confinement. 


\section{$2 \mathrm{BHL}$ Biodiversity Heritage Library}

Morgan, Thomas Hunt and Shull, A. Franklin. 1910. "The Life Cycle of Hormaphis Hamamelidis." Annals of the Entomological Society of America 3, 144-146. https://doi.org/10.1093/aesa/3.2.144.

View This Item Online: https://www.biodiversitylibrary.org/item/38713

DOI: https://doi.org/10.1093/aesa/3.2.144

Permalink: https://www.biodiversitylibrary.org/partpdf/193743

\section{Holding Institution}

Smithsonian Libraries

\section{Sponsored by}

Smithsonian

\section{Copyright \& Reuse}

Copyright Status: NOT_IN_COPYRIGHT

This document was created from content at the Biodiversity Heritage Library, the world's largest open access digital library for biodiversity literature and archives. Visit BHL at https://www.biodiversitylibrary.org. 